\title{
Letter to Editor
}

\section{Bullous Reaction on Tuberculin Skin Test}

Sir,

The tuberculin skin test (TST) also called Mantoux test is widely used to detect infection with Mycobacterium tuberculosis although its role in diagnosis of tuberculosis is limited. The usual positive reaction denotes a delayed hypersensitivity reaction that manifests as erythema and induration that peaks at 48-72 $\mathrm{h}$ and subsequently resolves within a week. Abnormally exaggerated and accelerated reactions are extremely rare with TST. ${ }^{[1]}$ This communication describes such a case where a young girl developed a giant reaction with bullous formation following this test.

A 15-year-old female patient presented with low grade fever, anorexia, and weight loss over the last 4 months. She denied any history of cough, joint pain, pain abdomen, dysuria, or headache. Her past medical history and family history were negative for any chronic illness, i.e., tuberculosis.

Her general physical and systemic examination was normal except a deep seated left supraclavicular lymph node. Routine investigations of blood including blood counts, sugar level, liver function tests, renal function tests, HIV serology, and connective tissue profile were all normal except raised erythrocyte sedimentation rate. X-ray chest was normal and ultrasound abdomen revealed focal mesenteric thickening, enlarged pre- and para-aortic lymph nodes along with minimal ascites. A TST was performed using 5 TU of $0.1 \mathrm{ml} \mathrm{PPD}$ intradermally on the left forearm. She developed marked erythema and induration within $8 \mathrm{~h}$ and by $48 \mathrm{~h}$, it converted to a large painful bullous lesion of $25 \mathrm{~mm} \times 30 \mathrm{~mm}$ with induration of $5 \mathrm{~cm}$ [Figure 1] This lesion subsequently persisted for about a week and gradually reduced to finally disappear without ulceration or discharge at the end of 3 weeks. A fine-needle aspiration cytology of the left supraclavicular lymph node showed cytological features of tuberculosis and acid-fast bacilli on ZN staining. The local reaction at TST site was managed by reassurance and oral paracetamol. She subsequently completed 6 months' antituberculosis treatment that was uneventful and resulted in complete recovery.

Severe reactions at the TST site are rare and usually common in patients with active tuberculosis with high mycobacterial antigen load. ${ }^{[1]}$ The case presented here developed a massive bullous response which is very unusual and more severe compare to previously reported cases. ${ }^{[2]}$ An exaggerated response causing giant reaction to tuberculin has been occasionally described in patients with lepromatous leprosy and also in patients with latent tuberculosis infection. ${ }^{[3]}$ One should also remember that an exaggerated response to tuberculin may also reflect an atopy but in that case the reaction does not last

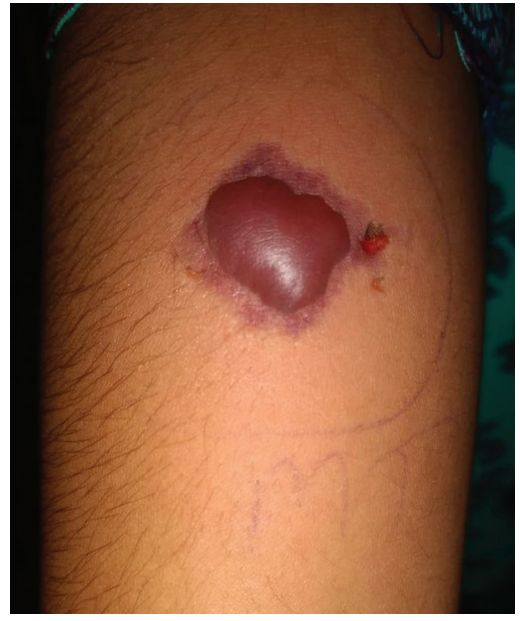

Figure 1: Large bullous reaction with induration at $48 \mathrm{~h}$ of tuberculin skin test

longer. Although the exact reason for such unusual reaction is poorly understood, it is believed that combined delayed hypersensitivity to tuberculin and less delayed phenomenon of excessive local exudation due to systemic features may be responsible. Such reactions in lepromatous leprosy has been linked to lack of temporary immune regulation with changing level of antigenic load. ${ }^{[4]}$ Giant tuberculin reaction has also been reported in a patient who received homeopathic drug Tuberculinum, with no evidence of active tuberculosis or leprosy. ${ }^{[5]}$

Although sensitive, TST is nonspecific for the diagnosis of tuberculosis and positive reaction has to be correlated with the clinical scenario in supporting the diagnosis.

\section{Declaration of patient consent}

The authors certify that they have obtained all appropriate patient consent forms. In the form the patient(s) has/have given his/her/their consent for his/her/their images and other clinical information to be reported in the journal. The patients understand that their names and initials will not be published and due efforts will be made to conceal their identity, but anonymity cannot be guaranteed.

\section{Financial support and sponsorship} Nil.

\section{Conflicts of interest}

There are no conflicts of interest.

Ramakant Dixit, Ashok Singh Charan, J. S. Broca ${ }^{1}$ Departments of Respiratory Medicine and ${ }^{1}$ Community Medicine, J. L. N. Medical College, Ajmer, Rajasthan, India 
Address for correspondence: Dr. Ramakant Dixit, Department of Respiratory Medicine, J. L. N. Medical College, Ajmer, Rajasthan, India. E-mail: dr.ramakantdixit@gmail.com

\section{REFERENCES}

1. Avasthi R, Chaudhary SC, Mohanty D. Giant mantoux reaction. Indian J Med Microbiol 2009;27:78-9.

2. Loganathan N, Hadda V, Madan K, Mohan A, Khilnani GC, Guleria R. Bullous Mantoux Reaction. N Z Med J 2015;128:101-2.

3. Bansal R, Sharma PK. Exaggerated Mantoux reaction in a case of latent tuberculosis infection (LTBI). Indian J Tuberc 2012;59:171-3.

4. Waters MF, Stanford JL. Giant reactions to tuberculin in lepromatous leprosy patients. Int J Lepr Other Mycobact Dis 1985;53:546-53.

5. Syrigou E, Gkiozos I, Dannos I, Grapsa D, Tsimpoukis S, Syrigos K. Giant tuberculin reaction associated with the homeopathic drug tuberculinum: A case report. Clin Infect Dis 2014;58:e119-21.
This is an open access journal, and articles are distributed under the terms of the Creative Commons Attribution-NonCommercial-ShareAlike 4.0 License, which allows others to remix tweak, and build upon the work non-commercially, as long as appropriate credit is given and the new creations are licensed under the identical terms.

\begin{tabular}{|l|l|}
\hline \multicolumn{2}{|c|}{ Access this article online } \\
\hline Quick Response Code: & Website: \\
\hline & www.ijrc.in \\
\cline { 2 - 2 } & \\
\hline
\end{tabular}

How to cite this article: Dixit R, Charan AS, Broca JS. Bullous reaction on tuberculin skin test. Indian J Respir Care 2021;10:162-3.

Received: $02-05-2020$

Accepted: 21-07-2020

Revised: 08-05-2020

Published: 19-06-2020

() 2020 Indian Journal of Respiratory Care | Published by Wolters Kluwer - Medknow 